des éclaircissements qui nous permettent de mieux comprendre l'histoire et la poétique du récit bref dans l'Europe de la Renaissance et de l'âge baroque.

hervé-thomas campangne, University of Maryland, College Park

\title{
Bussels, Stijn. \\ Spectacle, Rhetoric and Power: The Triumphal Entry of Prince Philip of Spain into Antwerp.
}

"Ludus" Medieval and Early Renaissance Theatre and Drama, 11. Amsterdam: Rodopi, 2012. Pp. 258 + 38 ill. ISBN 978-90-420-3471-6 (paperback) US \$77.

There is a tendency, at times, to look at early modern festivities, such as formal entries of rulers into cities, as little more than display and diversion. When, however, we take into consideration the amount of time, effort, and money that went into such events, as Stijn Bussels very effectively does in this book, we realize that these "diversions" were anything but. Just a glance at the economics of a royal entry should be enough to inspire modern scholars to formulate a more nuanced understanding of the significance such entrances held for an early modern audience. As Bussels points out, the formal entry of Emperor Charles V and his son Prince Philip into Antwerp on 10 September 1549, though only a one-day event, cost the city of Antwerp twice as much as the new city hall they built for themselves ten years later (10-11). This is because the "event" consisted not only of a rich and lengthy parade and elaborate triumphal arches and decorations erected along the processional route into town, but also of many tableaux vivants, battle arrays, tournaments, fireworks, and more - all in an effort to make an important point. While Charles V was coming to Antwerp in order to introduce his son Prince Philip to his Netherlandish subjects as his heir and their future lord, the city was welcoming the royal pair as partners in a commonwealth of business, culture, politics, and power. Seeing the entry as a "performative" event that was meant to bring about a "renewal," Bussels examines "what was at stake and what strategies were employed by the city fathers to make the desired power relations open for discussion and acceptable" (12). 
After a solid introduction that provides the background not only to the city of Antwerp in the sixteenth century but also to some of the major players in the organization and commemoration of the royal entry, the book is divided into four chapters. The first discusses the various sources available and compares the information they provide: the official record composed by Cornelius Graphaeus (the humanist scholar in charge of devising and organizing the festivities) and published and disseminated in Latin, Dutch, and French right after the event; the eye-witness description penned in diary style by the Spanish humanist and courtier Juan Cristobal Calvete de Estrella; the 24 prints etched by the eminent Dutch artist Pieter Coecke van Aelst, depicting various arches and tableaux vivants along the route; and archival materials that have survived the ravages of time and fire. The second chapter looks at the politics of the event by focusing on the self-images that the ruler and the city wished to present to one another, especially in light of the extensive negotiations that unfolded in the months previous to the entry. In this context of negotiations and affirmations, special attention is given to the Blijde Inkomst (Joyous Entry), or Inauguration Charter, dating back to 1356, that set out the terms of reference or balance of power established between the monarch and the people of Brabant (at that time Antwerp was part of the Duchy of Brabant). The ideas expressed in the charter and visualized in the royal entry are then contextualized by Bussels in the realpolitik of sixteenth-century Antwerp and the Low Countries, taking into particular account the view of the "Monarchomachs" and the "Sovereignists." The third chapter moves only slightly away from politics when it looks at the Antwerp entry in relation to other contemporary entries, in particular those of Charles V into Genoa (1533) and Lille (1549), or of King Henri II of France into Paris (1549). The fourth and final chapter sets the Antwerp entry in the context of the studia humanitatis that were the forma mentis not only of the royal pair but also of the leading citizens of Antwerp. This last chapter is especially fascinating because it shows the entry into Antwerp as a product of humanism, in particular Erasmian humanism, which it then ties closely to the political context mentioned earlier, though clearly on a more intellectual and cultural level.

The analysis carried out and the insights expressed in the volume advance our understanding of royal entries, official festive celebrations, and power dynamics between rulers and subject cities in sixteenth-century Europe. This, in turn, makes for a fascinating read and a solid contribution 
to scholarship. I cannot, however, refrain from lamenting the low quality of the editorial work evident in the volume. For example, the numerous spelling errors present in the text (Alberti's Della picture, 127) should have been caught and corrected; English grammar errors should have been fixed ("God's gospel has reborn" 18); missing words ought to have been noticed and supplied. Similarly, this reader was struck by some words or expressions such as "the growing of Antwerp" (27) or "the Habsburgers" (228 and passim). Some sentences should simply not have been allowed to stand ("Central issue in this chapter is the question whether in its visualisation of its bargaining power the Antwerp entry was exceptional," 133). Nor can I pass over in silence some factual errors that should have been caught at the peer-review or copy-editing stage. For example, Petrarch's Trionfi are not "a series of sonnets" (70,150), but six very long capitoli (or chapters) in terza rima. Erasmus was not the tutor or teacher of Emperor Charles V $(29,123-24,125)$; this role belonged to Adriaan Florenszoon Boeyens, who would later become Pope Adrian VI. Along the same lines, it might have been better to refer to Apuleius's Metamorphoses (9) by its more common title of The Golden Ass so as not to confuse it with Ovid's much more famous work by the same title.

In spite of these unfortunate lapses, however, the volume stands as a major contribution to our understanding of royal entries in early modern Europe and the politics of power evident in the theatrum mundi that such entries staged for participants and spectators alike.

KONRAD EISENBICHLER, University of Toronto

Campbell, Julie D. and Maria Galli Stampino (eds.).

In Dialogue with the Other Voice in Sixteenth-Century Italy: Literary and Social Contexts for Women's Writing.

The Other Voice in Early Modern Europe: The Toronto Series, 11 . Toronto: Iter Inc. and The Centre for Renaissance and Reformation Studies, 2011. Pp. x, 385. ISBN 978-0-7727-2085-6 (paperback) \$32; 978-0-7727-2087-0 (online) \$32.

In Dialogue with the Other Voice in Sixteenth-Century Italy provides a valuable resource for students, teachers, and scholars who wish to learn more about 